\title{
Gilles Deleuze'ün Sanatı ve Francis Bacon ya da Duyumsamanın Mantığı
}

\author{
Engin ÜMER *
}

\section{Giriş}

Fransız düşünür Gilles Deleuze, güncel sanat pratiklerinde fikirlerinden yararlanılan bir isim olarak çokça bilinirken ne yazık ki ülkemiz lisans ve sonrası sanat eğitimi içinde, en azından sanat felsefesi gibi bir alanda geniş ölçüde tanıtılmayı beklemektedir. Deleuze'ün sanat felsefesi ve teorisi açısından önemli olmasının nedenleri sanatı bir düşünme alanı olarak önerirken özel olarak sanat üzerine düşünme konusunda sanat eserini çözen ve açık ve net şekilde onu anlayan değil, onu yorumlayan ve üreten bir dili önermesidir.

Bu yazıda Deleuze'ün düşüncesinin her yerine sinen sanat ve özel bir ilgi olarak sanat düşüncesi ele alınmıştır. Amaçlanan, alanla ilgili teorik kısımda güncel bir düşünürün fikirlerine, geniş ölçekli külliyatına en azından sanat konusunda bir giriş yapabilmektir. Çalışmada konu hakkındaki birincil kaynaklar ve Deleuze'ün düşüncesini yorumlayan güncel metinlere yer verilirken, Deleuze'ün konu hakkındaki görüşleri ve bunların nasıl bir kavramsal ve anlam düzeni gösterdiğinin incelenmesi ve betimi de araştırmanın esas aldığı yöntem olmuştur.

Gilles Deleuze'ün felsefesi çağdaş Fransız felsefesinin de karakteri olan geleneksel düşünmenin kökten eleştirisini yapar. Deleuze'ün amacı, “insanın deneyim alanına yönelik ortaya koyduğu yaratımların bir sorgulamasını yapmak ve bu alanların 'ne'liğini yeni bir bakış açısıyla değerlendirmektir” (Sütcü, 2005: 25). Bu yüzden Deleuze, başlangıç için bir dizi ismin felsefesi içinde dolanmış ve onları yeniden düşünmüştür. Deleuze'ün Nietzsche, Lucretius,
Spinoza, Hume, Bergson üzerine yazdıkları O'na Hegel düşüncesi, fenomenoloji ve varoluşçuluk gibi Fransa'da baskın olan felsefelerden uzaklaşması için bir mesafe sağlamıştır (Bogue, 2002: 12). Batı felsefesinin düşünme şekillerinden işleyişine kadar ele alındığı bu sürece Deleuze, insan varlığına dönük bir düşünme imkânı olarak sanatı da dâhil etmiştir.

Elbette Deleuze'den bahsetmek, Felix Guattari'den, Guattari'den bahsetmek de Deleuze'den bahsetmek demektir. İkisinin de ortaklılarından önce ve sonra yazdıkları eserler ne kadar önemli olsa da Deleuze'e ait olan Guattari'ye de aittir denilebilir. Bu çalışma, başlığında sadece Deleuze'ü taşıyor olsa bile kaçınılmaz olarak Guattari'yi de anmış olacaktır. Deleuze kaçınılmaz olarak Guattari'dir ya da Deleuze ve Guattari'dir. Ronald Bogue, bu nedenle 'Deleuzoguattarici'likten' bahsedilebileceğinde bile israr etmektedir (Bogue, 2002: 22).

İkilinin ortaklıklarından neredeyse isimleriyle anılır hale gelmiş olan 'Anti-Oidipus', devamında 'Bin Yayla', 'Kafka: Minör Bir Edebiyata İçin' ve 'Felsefe Nedir?' kitapları çıkmıştır. Deleuze, Guattari ile ortaklığından önce ise bir dizi filozof hakkında yazdığı kitapları dışında felsefesinin ana hatlarının görülebileceği 'Anlamın Mantığı' ve 'Fark ve Tekrar'da geleneksel batı düşünmesinin işleyişini eleştirmek için "kavramsal -olmayan" ya da "kavramolmayan” önermiştir (Bogue, 2002: 13, 14). Deleuze'ün bu önerisinin sanat için karşılığının da sanatın kavrama bürünmeyen, dilden kaçan karakterde olduğudur.

Deleuze'ün sanatla ilgisi yazınla başlayan, res- 
me ve sinemaya geçiş yapan bir süreci göstermektedir (Sauvagnargues, 2010: 29). Bu süreç üç evrede özetlenebilir: "İlk yapıtlarından Différence et Répétition [Farklılk ve Yineleme]'a kadar, sanat konusu öncelikle yazının ayrıcalığında geçer. Guattari ve Anti-Oedipe'ten [Anti- Ödipus] itibaren düşüncenin edimsel dönemeciyle beraber, Deleuze bir yorum eleştirisine ve Mille Plateaux [Bin Yayla] sonrasında bütünüyle imgenin göstergebilimi ve sanatsal yaratıya kendisini adamasını olası kılan çokluklar mantığına girişir" (Sauvagnargues, 2010: 12).

Deleuze'ün görsel sanatlarla olan ilgisini, bu yazıda konu edilecek olan 'Francis Bacon Duyumsamanın Mantığı'nda ve iki cilt olan sinema kitabında yine diğer eserlerinde ve Guattari ile olan son ortaklığı 'Felsefe Nedir?'in son bölümünde doğrudan ve dolaylı değinmelerde görmek mümkündür. Bunlardan Bacon üzerine yazdığı kitabına geçmeden önce Deleuze'ün düşüncesinden hareketle sanat konusundaki fikirlerine kısaca değinmek gerekmektedir.

\section{Deleuzecü Bir Sanat Tanımı}

Felsefe, temaşa, düşünüm ya da iletişim değildir. Bir alan felsefeyi kendisi üzerine düşünmek için beklemez ve ona ihtiyaç duymaz (Deleuze, 2009a: 324). Felsefe diğer disiplinlerden çok da farklı olmayan ancak kendi araçlarıyla işleyen bir alandır. Bu nedenle Deleuze'ün sanat ilgisi, filozofun onu sahnelemesi için kavramların seferber etmesi, onun üzerine düşünerek, kendisini bekleyen eseri tamir etmesi veya sanatı iletişimin diline dökmesi şeklinde gerçekleşmez. Felsefe, bilim ve sanat gibi yaratma gücüne sahip ve icatlarda bulunan bir etkinliktir. Bu üçlünün ortaklığı olan 'yaratmak' ve 'icat etmek' ise sadece kendi birikimlerinin gölgesinde hareket etmeyerek, yaşamın içinde varlık bulmalarıyla anlam kazanır. Bu üçlünün asıl görevlerinden birisi de kaosa karşı düzen getirmeleridir.

Felsefe, bilim ve sanat gökkubbeyi yırtmamızı ve de doğruca kaosun içine dalmamızı isterler. Kaosu ancak bu bedel karşılığında yenebileceğizdir.... Filozofun kaostan beraberinde getirdiği, sonsuz olarak kalan, ama kesitsel bir içkinlik düzlemi çizen yüzeylerin üzerinde ya da mutlak oylumları içinde birbirlerinden ayrılmaz hale gelmiş değişimler'dir.... Sanatçının kaostan getirdiğiyse, artık duyu organında duyulurun yeniden üretimini kurmayan, ama, sonsuzu yeniden vermeye muktedir, organik-olmayan bir kompozisyon düzlemi üzerinde, bir duyulur varlık, bir duyum varlığı çatan değişiklikler'dir (Deleuze ve Guattari, 2001: 180).

Kaosla buluşma, her sanatçı gibi ressam için de 'her türlü klişeye meydan' okumaktır. Klişeler yüzeyde birikmiş, ressamı bekleyen çizgiler, lekeler ve kompozisyonlardır. Ressamın klişelerle mücadelesi kaosla mücadelesi değildir. Ressam kaosa giden yolda klişelerden faydalanır. Kaosla buluşmasında yeni duyumlar üreten ressam yeniden bir düzen kurmuş olur: "Sanat kaos değildir, ama kaosun görüyü ve duyumu veren bir kompozisyonudur" ve "sanat kaosla savaşır, ama onu duyulur kılmak için savaşır” (Deleuze ve Guattari, 2001: 182). Felsefe kavramlarla, sanat duyumlarla, bilim ise fonksiyonlarla işler ve kaosa karşı düzeni korurlar (Sütcü, 2005: 26). Bu şekliyle sanat, felsefe ve bilim gibi yaşam üzerine düşünürken, onu dönüştürür. "Hayatı dönüştüren" bir güç olarak sanat, bir şeyleri betimleyen ve ifade eden bir durumdan daha fazlasını sunmaktadır (Colebrook, 2004: 22). Sanat eseri, hayatın kuvvetlerini dağıtır.

Deleuze, temelin olmadığı bir yaşantı ve deneyimi yani insanın var olma tarzları üzerine düşünmüştür. Temelsiz bir düşünme, düşünme ve diğer edimlerin güvenini sağlayan, emniyet görevi gören bir unsurun olmaması, Deleuze'ün düşüncesinde sıkça görülen "icat etme, yaratma ve deneme" imkânlarını karşımıza çıkartır (Colebrook, 2004: 10). Sanatta icat eder. Tıpkı felsefe ve bilim gibi:

0 halde, siz, sinema yapanlar, siz ne yapiyorsunuz? Sizin icat ettiğiniz şey kavramlar değil; bu sizin işiniz değil, sizin işiniz, bloklar halindeki hareket/süreyi icat etmek. Eğer bir hareket/ süre bloğu yapıyorsak, belki de o zaman sinema yapıyoruz. Söz konusu olan bir hikâyeyi hatırlatmak ya da reddetmek değildir. Felsefe de hikâyeler anlatıyor, kavramlar ile anlatılan hikayeler. Sinema ise hareket/süre blokları ile anlatıyor hikâyelerini. Resim de bambaşka bir biçimde bloklar icat ediyor. Bunlar kavram blokları ya da hareket/ süre blokları değil, fakat çizgi/renk bloklarıdır. Müzik de kendine has bloklar icat ediyor. Tüm bunların yanında bilimin daha az yaratıcı olduğunu söyleyemeyiz. Zira bana kalırsa, bilimler ve sanatlar arasında 
çok da karşıtlık olduğunu söyleyemeyiz (Deleuze, 2009a: 325).

Deleuze, bilmeyi güven altına alan kurucu unsurların bir süre sonra normatif bir düzene dönüşebileceğini düşünmekteydi (Colebrook, 2004: 10). Deleuzecü köksapçı düşünmenin batı felsefesinin ağaç biçimli düşünmeye karşılık getirdiği öneri, temellerin kolaylıkla def edilebileceği ve tüm güçlerin etkileşimlerle varlık bulabileceğidir. Batı düşünme ve sanat geleneğinde sanatın ideal olanla ilişkisi ve onu göze getirmesi karşısında Deleuze'ün düşüncesine göre sanat bir yanılsama mı ortaya koymalıdır? Sanatın tasvir ettikleri bir anlatıyı mı göstermelidir? Bu soruların cevabına giden yol Deleuze ve Guattari'nin ontolojisinden geçmektedir. Onlar eleştirdikleri geleneksel batı düşüncesinin özdeşlik, benzerlik, zıtlık, analoji ilkeleri ve hiyerarşik, tarihselci, majoratif, aşkınsal ve temsilci özellikleri karşısına kendi fark ontolojisini koyarlar (Kılıç, 2013: 18). Fark ontolojisi, temsil etmeyi eleştirerek onu başka bir anlama dönüştürür. Bunu net bir şekilde anlamak için Deleuze'ün 'simulakrum' kavramına bakmak gerekmektedir.

Simulakrum düşüncesiyle Deleuze, Platoncu imgeyi başka türlü düşünmeyi önerir. Platoncu imgenin kopyalar ve hayaller/rüyalar ayırımında zararlı olan ikincilerin simulakra hali, ideanın tehlikeye düşürüldüğ̈̈, onun taklidi bile olmadığını, bu nedenle de yasaklı olması gerektiğini göstermektedir. Platon'un 'Devlet'inden kovduğu şaire ve sanatçıya ait olan simulakrum, ideaya dair bir şeyler içermediği gibi, ardındaki boşluk ile izleyeni karşılar ve bireyin daimi şekilde mağaranın içinde kalmasını sağlayarak onun Platon'un arzuladığı sitenin ideal vatandaşı olmasını engellemiş olur. Deleuze ise simulakrumun bu boyutuna olumlu bir yaklaşım göstererek onun 'gerçek' olduğunu söyler (Kılıç, 2013: 62). Deleuze, Nietzsche'nin Platon için başlattığı eleştiriyi devam ettirmektir (Bogue, 2002: 78). Temsile karşı olan bu tavır üretim, değişim ve yaratımın değerli olması için fikir vericidir. Sanat simulakrum olarak bir temsil ortaya koymayı üretim hali olarak Platon düşüncesinde yasaklı olan halinden izler taşıyarak Deleuze'de anlam bulur (Colebrook, 2004: 26). Böyle bir imgeyle karşılaşan kişinin konumu, ona dalarak kendisini kaybeden değil, onun sunduğu düşünme imkanıyla buluşması şeklindedir (Sauvagnargues, 2010: 30). Burada akla kişinin imgeyi düşünürken bir söze gereksinim duyabileceği gelir. Ancak Deleuze için imge "sözce değildir ve sözel olmayan bir duyumun mantığını gerektirir, anlamına mantığını değil” (Sauvagnargues, 2010: 31). Simulakrum da söze kavuşmamasıyla kişinin anlamdan uzaklaşmasını sağlamamakta, kişiyi duyumun içinde başka bir anlam alanına doğru hareket ettirmektedir.

İmge, özne ve nesnenin birbirlerinden ayrılmasına işaret etmektedir. Deleuze'ün ontolojisinin bir özelliği olan özdeşlik karşıtlığının (Kılıç, 2013: 35) sonucu olarak bu durum sanatçının çevresini saran dünya ile ilişkisinde kendisinin merkezde olmadığı gibi bir sonuç çıkartmaya izin verirken, aynı zamanda nesnesinin de kendisini kısıtlamadığını, bir formülle ele gelmediğini düşündürtmektedir. Öznenin merkezde olmaması onun oluş halinde düşünülmesini sağlamıştır. Özne, nesnesini ele aldığında ona dair ürettiği tasarımlarında sadece kendi elindeki prosedürlerle buluşan, bunu yasallaştıran bir eylem göstermiş olur. Nietzsche'nin batı düşüncesine köklü saldırısının nedenlerinden de olan bu duruma karşılık Deleuze, O'nun “ebedi dönüş” fikrini kendi düşüncesi içinden seslendirir.

Deleuze için, ebedi dönüş, öznenin koşulların kısıtlılığı ve belirleyiciliği karşısında kendi dürtülerini kendiliğinden gerçekleşmesidir (Ballantyne, 2012: 55). Öznenin bu yönü tarih boyunca gerilere itilmiştir. Deleuze, toplumsal kurumlar içinde üretilen, sistemi ikili karşıtlıklar olan özneden, normalliklerinin bozulduğu, onun ruhunda çatlaklar açıldığı özneden ve kendisinin önermiş olduğu, yersiz yurtsuz hale gelmiş, toplumsal ve içinde oluşan çatlakların ötesine geçmiş yaratıcılık ve arzu içinde varlık bulan özneden bahseder (Su, 2014: 191, 192). Bu son özne halinde kendiliğinden çıkan yaratıcı bir güç vardır. Çünkü arzuları kodlanmamış ve düzenlenmemiştir. Bu özne tasarımı psikanalizin geliştirdiği özne yaklaşımına karşı eleştirel bir özellik içermektedir. Freud'da da görülen ve 0'na kadar gelen düşünme geleneğinde arzunun bir eksikliğe karşılık geldiği, nesneler dizisiyle bu eksikliğin kısmen kapandığı düşünülmüştür. Buna göre özne olma sürecinde, arzu, nesnelere yapılan bir yatırım olarak giderilmeye çalışılır. Freud'un psikanalizinde ödipus süreci bu durumun sahnelemesi olarak arzuyu anne- baba ve çocuk üçgeni içine oturtur. Böylelikle arzu, nesnelerine dağıtılır ve toplumun 
düzenini korunmasında görevini kazanır.

Deleuze ve Guattari'nin arzunun bir eksiklik olmadığı ve özneyi keserek, her şeyi aştığı düşüncesi yaratıcılık konusunda potansiyeller barındırmaktadır. Arzu diğer her şeyde olduğu gibi üretime karşılık gelmektedir.

0 halde her şey üretimdir: üretimlerin üretimleri (productions de productions), eylemlerin ve tutkuların; kaydetmelerin üretimleri (productions d'enregistrements), dağıtımların ve gönderim noktalarının; tüketimlerin üretimleri (produstions de consommations), bedensel hazların, kaygıların ve acıların. Kaydetmeler anında tüketildiği, harcandığı, ve tüketimler derhal yeniden-üretildiği için her şey üretimdir. Sürecin ilk anlamı şöyledir: kaydetmeyi ve tüketimi bir ve aynı sürecin üretimleri kılmakla onları üretimin içine dahil etmek... Süreç teriminin ikinci anlamı budur: insan ve doğa karşı karşıya gelen iki terime benzemez, nedensellik, ihtiva etme veya ifade etme ilişkileri içinde dahi değildir (sebep-sonuç, özne-nesne vb.); ama onlar üretici ile ürünün bir ve aynı temel gerçekliğidir. Süreç olarak üretim, tüm ideal kategorileri geride bırakır ve arzuyla olan ilişkisi içkin bir ilkeye dayalı bir devre tesis eder (Deleuze ve Guattari, 2012: 16, 17).

Deleuze ve Guattari'nin psikanaliz eleştirileri ve psikanalizin Marks'la sentezine doğru yaptıkları yeniden okumalarında öznelliğin ödipus öncesi, onların çokça bilinen ifadesiyle yersiz yurtsuzlaştırılmış hali sanatçının görünümü olarak düşünülebileceği gibi onun yaratıcılığının imkânlarına dair bir açıklama sunmaktadır. Deleuze'ün sanatında kültürü kuran ve onu ileriye doğru kendi düzeni içinde atılım göstermesini sağlayan bir üst sanatçı motifi görülmez. Dehanın öznelliği ne kadar dizginsiz olsa bile kişisel olana dairdir. Sanatçının eserindeki kişisellik ise arzunun nesneleriyle donatılmış halde, kendisinin merkezde olduğu şekildedir. Buna karşılık ise Deleuze için kişisel olanı silen metnin düzenlemeleri söz konusu edilmelidir (Sauvagnargues, 2010: 16). Deleuze, yaratıcılığı temelsiz bir var olma tarzı olarak kariyerinin ilk zamanlarından bu yana düşüne gelmiştir. Hayat, bir kurmaca olarak yaratımın ürünüdür (Colebrook, 2010: 13). Sanatın meydana getirdiği "verili olmayan duyguların tahayyül” edilmesidir
(Colebrook, 2010: 141).

Sanatçının yaratımının sınırsızlığı tipik, karikatürleştirilmiş bir sanatçı görüntüsü olarak onun deliliğin sınırlarında gezinmesi anlamına gelmez. Sanat ve delilik konusunda Deleuze, deliliğin sekteye uğrama olduğunu düşünür. Nevroz ya da psikoz ve diğerleri sadece engelleyicidir. Çünkü bunlar Freud'un ödipus sahnesinin figürleridir. Bunun yerinde sanatçının konumunun toplumdan kaçar gibi görünen ancak onun sınırları içinde kalan sahte bir yolculuk değil, tersine yaşamın yaratıcı üretiminde onu kurgulamasıdır. Yazar, hekimdir. Hekimin görevi de semptomları bulmak, "eksik olan bir halk icat" etmektir (Deleuze, 2013: 12). İcat edilmeyi bekleyen halk, tarihin aktörü olacak olan bir zümre değildir. Halk, minör haldedir (Deleuze, 2013: 13). Sanat kendisini bekleyen halk için psikanalizin yaptığına benzeyen bir etkide bulunacaktır. Nasıl ki psikanaliz, bilinçdışını özne için buz dağının görünen yüzeyinde sakin bir hale görünmesine yardımcı oluyorsa, sanatta tersi bir şekilde toplumsal düzeydeki bilinçdışı$\mathrm{n}$ izleyicisine sunar. Beraberinde de toplumsal düzene ait olan katmanlı düzenleri gösterir (Goodchild, 2005: 298). Eserin bu gücü, izleyicisine bakan ve ona yönelmesiyle onda varlık gösteren potansiyelleri, içerlerde bir yerde olanları harekete geçirecektir.

Deleuze ve Guattari'nin sanat ile ilgili seçimlerinin modernist estetikten gelen yapıtlar olduğu görülür. Bu tutum, düşüncelerinin sürekli olarak modern sanata ait eserlere yönetilmesi gerektiği anlamına gelmemelidir. Onların ilgisi daha çok yapıtın "bir kültürel ürünün değişmezi mi yoksa bir oluşu mu ifade ettiğidir” (Goodchild, 2005: 293). Sanat yapıtının bu konumları, ilkinin kültürün düzenine tabi olması, onu yüceltmesi ve onun değişmezliğini vurgulamasıyla, ikincisinin ise tersine kültürün sürekli olarak açılması ve dağıtılmasıyla, yeniden bir düzene getirilmesi ve yeniden bu düzenin bozulmasıyla ilgilidir. Yapıtın direnci, onun oluş halinde olabilmesiyle ilgilidir. Yapıt, "ne oldu?" (Deleuze, akt. Goodchild, 2005: 296) sorusuyla “travmatik bir” karşılaşma sunar (Goodchild, 2005: 296).

Fakat sanat, travmayı aşar, çünkü şeyleri farklı bir biçimde görmemizi ve duyumsamamızı sağlar. Kişi, travmanın sonucu olarak, olaylar için bir amaç arayabilir, fakat hiçbir şey bulamayabilir. Kişi bir sanat yapıtını 
sorguladığı zaman, "anlam”, bir başka düzeyde aranmalıdır... Hem algı hem de nesne, saf duyarlık varlığını kendi haline bırakmak için çıkarılır. Kodlar ve varsayımlar sayesinde dünyanın gündelik örgütlenmesiyle uyuşan algıların ve duygulanımların, kompozisyon ilkesi sorununu ortaya atmak için çıkarılmaları gerekir (Goodchild, 2005: 296).

Sanat, kendisini saklayandır. Bu eserin maddi boyutunun zamana direnen yönünü değil, ondan bağımsız vaziyette olan bir saklamayı işaret eder. Bu saklama durumunda, yapıta ait olan kendiliğinden hal, duyumlar kitlesi olarak eserdeki duyum varlığıyla ilgilidir (Deleuze ve Guattari, 2001: 146, 147). Deleuze ve Guattari'nin terminolojisinde duyumlar kitlesi olarak sanat yapıtı, "algılam ve duygulamların bir bileşimi"dir (Deleuze ve Guattari, 2001: 146). Bunlar kişiye bağlı, onda gerçekleşen, ancak içlerinde olayların izlerini aşan varlıklardır. Temsil edici görevleri olmadı̆̆ gibi bunu aşmalarıyla vardırlar:

Duygulam, hissedilemeyecek denli derin olan bir iç dinamizmdir; bir içtepi olarak kendisini yineleyen eylemler aracılığıyla gözlemlenebilir ancak. Duygulamı hissedilebilir kılmak için, duyumlar ya da titreşimler, benzerlik ya da özdeşlik olmadan, seçilemez oluncaya kadar birbirlerini canlandırırlar, yinelerle ve birbirlerine dönüşürler... Duygulamlar, yaşanabilen deneyimi aşar. Bir yazınsal romanda karakterler, "gerçek hayatta" olamayacak ya da deneyimlenemeyecek denli canlıdır; onun yerine, yaşam olasılıklarını ya da dünyanın anlarını cisimleştirirler (Goodchild, 2005: 297).

Sanatçı, "algılam veya görülerle bağlantılı olarak duygulanımların göstericisi, duygulamların mucidi, duygulamların yaratıcısıdır" (Deleuze ve Guattari, 2001: 157). İzleyici eserin kendisine verdiği duygulamlarla bir "halinegeliş" durumu kazanır. Oluşun, izleyiciye eser tarafından sunumu olarak bu "haline-geliş̧"teki sınır silikliğinde estetik deneyimi yaşatır. Sanat böylelikle dilin içindeki yabancıyı çıkartmış olur. Deleuze ve Guattari'nin bahsettiği haline-gelişi meydana getiren duygulam, sadece doğanın kendisinde değil, ifade düzlemlerindeki kırılmalarla da gerçekleşir. Sanatçının hekimliği burada kendisini göstermektedir. Olağan düzenin, her bireyin içinde bulunduğu kesinliğin aslında ne kadar kolay kırılganlaşabileceğini göstermesiyle (Deleuze ve Guattari, 2001: 158).

\section{Bacon'un Tasvirleri}

Deleuze'ün imge düşüncesi hatırlanırsa, resmin şeyleri temsil etme gibi bir görevi yoktur. Resim "duyguyu resmeder" (Sauvagnargues, 2010: 161). Bu duygu boyutu ise, güç ile ilgilidir. Böyle bir resim de anlatısal düzeylerden bağımsız halde gösterdiği şeyin suretini göstermeyi bırakan bir ressamın eseridir. Deleuze'ün bugünün sanatından beklediği de budur (Goodchild, 2005: 298). Bir resim klişelerden, "kendiliğinden olan"dan (Deleuze, 2009b: 40) ve sansasyonel olandan uzaklaştıkça değerli olmaya başlar.

Ressamın beyaz bir yüzey karşısında olduğunu düşünmek hatadır. Figüratif inanç bu hatadan kaynaklanır: Ressam gerçekten beyaz bir yüzey karşısında olsaydı, model işlevi gören dış bir nesneyi orada yeniden üretebilirdi. Halbuki üretemez. Ressamın kafasında veya etrafında olan her şey, o daha işe başlamadan, kimisi daha virtüel, kimisi daha aktüel olarak tuvaldedir. Tüm bunlar virtüel ya da aktüel imgeler olarak tuval üzerinde mevcuttur. Ressamın işi beyaz yüzeyi doldurmak değil, daha ziyade boşaltmak, tıkanıklığını gidermek, temizlemektir. Öyleyse ressam model işlevi gören dış bir nesneyi tuval üzerinde yeniden üretmek için değil, zaten orada olan imgeler üzerine, işleyişi model ile kopya ilişkilerini tersine çevirecek olan bir tuval üretmek için resmeder (Deleuze, 2009b: 82).

Ressamın bu ayıklama işlemine girişmesinin yolları vardır. Ressam her zaman yeni yollar peşinde olarak tuvalde kendisini bekleyenlerden kurtulmaya çalışır. Bugünün resmi ise bu açıdan üç durum içinde düşünülebilinir: Soyutlama, dişavurum ve figüral (Deleuze, 2009b: 187). Jean Francois Lyotard'a ait olan 'figüral' kavramı, Bacon'un resminin figüratif olandan ayırır. Figüralin görevi tıpkı soyutlama gibi figüratiften kaçmaktır (Deleuze, 2009b: 40). Figüral, figüratifi engelleme, anlatısal olma veya illüstre etme durumunun önüne geçmeyi sağlar. Figüratifin anlatısal ve illüstre edici boyutu Bacon'un resimlerinde figürlerin tecrit edilmesi ve onların temsil ettiği modeli terk etmesiyle ortadan kalkar. Çünkü tecrit, figürler arasındaki olay örgüsü kurulmasını sağlayan iletişimin kesilmesini sağlar (Deleuze, 2009b: 14). 
Bacon'un resimlerinde görülen insanlar, nereden gelmektedir? Eğer bir model Bacon için eksiltilecek bir fazlalıklar yığınıysa bu ayıklamanın sonunda insana ait olanlar nelerdir? Bir bozulma, ancak nedensiz görülen bir etkenin yüz ve bedenin tertiplerini değiştirmesi insana ait olanlardan bir şeyleri söküp alır. Deleuze, Bacon'un kafayı göstermek için yüzdeki fazlalıkları temizlemeye gittiğini yazar. Bu temizlemeyle insana dair olanlar ayıklanarak hayvan olana doğru gidiş gelişler meydana gelir. Hayvana dair olan ile hayvan biçiminin anımsatıcısı ya da türevi değil, "çizi olarak" hayvana ait olanlar insan olanlarla bir araya gelir. Bu ise bir melezlik değildir (Deleuze, 2009b: 29). Grotesk ve fantastik olan bir birleşim hiç değildir. Groteskin yaşama dair şeylerin düzeninin kıyısında ya da başka bir âleme dair olması ile rüya sembolleri ve ilkel imge düzenlerindeki yarı mitsel betimleme fikri Bacon'ın resimleri için yeterli bir açıklama olarak görülemez.

Biçim şişer, dağııır, bilinenden abartılar ve silmelerle başkalaşır ancak grotesk ve fantastiğin dili bunlar için kesin bir yaklaşım sağlamaz. Deleuze'de, Bacon'un yüzden kafaya doğru yaptığı yolculuğun son uğrağında "hayvanla insan arasında bir ayırt edilemezlik, karar verilemezlik bölgesi meydana" getirdiğini yazar (Deleuze, 2009b: 29). Bu ara bölge bir aradalıkların olağan dışı birleşimi değil, aslında hayvan ile insan arasındaki ortaklıkta buluşmadır (Deleuze, 2009b: 29). Bu ortaklık, Bacon'un resimlerinde teninden ve kemiklerinden sıyrılmış, kendisine yönelen kuvvetlerin ortasında kalmış olan ettir. Resimlerde görülen et, kendi başına bir nesne olarak izleyeni beklemez. "Acı çeken insan bir hayvan, acı çeken hayvansa bir insandır" diye yazan Deleuze bunu "oluşun" gerçekliği olarak görür (Deleuze, 2009b: 33). Bacon, Deleuzecü anlamda oluşun bir durumun diğeriyle buluştuğu ve onda bütünleşmeyip tekrar bir diğerine doğru uzandığı bitimsiz et halini göstermektedir.

Et, duyumun açımlanışına katılsa bile, duyum değildir. Duyum bedenleşir derken fazla ileri gidiyorduk. Resim, eti bazen etkırmızısıyla [incarnat] (kırmızı ve beyazın üst üste gelmesi), bazen kırı tonlarla (eşit olmayan oranlarda tamamlayıcıların birbirine eklemlenmesi) yapar. Ancak duyumu kuran şey, derisi yüzülmüş bir hayvanın, soyulmuş bir meyvenin, ayna karşısındaki Venüs'ün mevcudiyeti gibi, en çekici, en zarif çıplaklığın içinde, et-kırmızısı yüzeylerin altında beliren, hayvan, bitki, vb... haline-geliştir; ya da, insanla hayvanın ayırt edilmezlik bölgesi olarak, eriyişte, kaynayışta, kırık tonların akışında beliriveren hayvan, bitki, vb.. haline-gelişti... (Deleuze ve Guattari, 2001: 160).

Cezanne'ın resimlerinin fenomenolojik ifadeyle dünyada olma özelliği, duyumsamanın elde edilmesine karşllıktır. Cezanne, "figüre giden yola basit bir ad verir: duyumsama. Figür duyumsamayla ilişkili duyulur biçimdir; doğrudan doğruya sinir sistemine etki eder, yani tene" (Deleuze, 2009b: 40). Duygulama doğru bir gidiş ve bunun ifadesinde ressam, çizgi ve renklerle bunu gerçekleştiriyorsa her kişinin de kullanabileceği yöntemleri vardır (Deleuze ve Guattari, 2001: 152). Bu, Deleuze'ün 'halinegeliş' ifadesini akla getirir. Cezanne gibi, birey de dünyayı temaşa ederek haline-gelmektedir.

Duyumsama düşüncesini göz önünde bulundurarak sanatçı-öznenin nesnesiyle gerçekleştirdiği ilişki, birinin diğerine bir tür tahakküm, onu ele geçirme ya da kendisini ona yansıtma olarak değil, ikisinin bir arada erime durumu olarak görülebilir (Deleuze, 2009b: 40). Duyumsama, ressamın yaşadığı bir deneyim, izleyicinin resimde yaşadığı bir deneyimden öte resmedilen, yüzeyde olanın kendisidir. Cezanne, peyzajlarında gördüğü alanın bir eşini, onu anımsatan halini değil o mekanla olan ilişkisindeki halini, sadece kendisinden değil, mekanın kendisiyle olan durumunu resmetmiştir. Bu yüzden duyumsama, ressamın izlenimleri gibi ele alınsa da temsil edici değildir. Cezanne gibi Bacon için de yüzeyde varlık bulanlar imgelerin duyumsama olarak varlıkları, temsil etmeye, figüratif olmaya karşıt olmasıyla düşünülebilir (Deleuze, 2009b: 41, 42). Bu açıdan Bacon, 'resminde şiddeti gösterir' denildiği zaman bir yönüyle hatalı bir öneride bulunulmuş olur. Dikkat edilmesi gereken şiddetin nasıl varlık bulduğudur. Acı içinde gösterilen, İspanyol ressam Diego Velazquez'in papa resmini yorumladığı çalışmasında Bacon'un papa imgesinin çığlığının nedeni kesin değildir. Bir yerden gelen bir etkinin, Bacon'un papasını zedeleyen veya dağıtan bir şiddetin yüzeyde varlı̆̆ı görünmez. Sandalyesinde kendisini keser gibi duran dikey çizgiler neden gibi görünse de bu kesin 
değildir. Bacon'da çığlığı resmetmek istediğini söylerken, onun nedenine dair bir şeylerin olmamasını istediğini ifade etmiştir (Deleuze, 2009b: 43). Çığlık, izleyicisinin karşısına sahnesiyle çıkmaz. Nedenleri ve olası sonuçları söz konusu edilmez. Bacon, modelleriyle ilişkisinde onlara karşı iletişimde olmayı sağlayacak bir düzene müsaade etmez. His, modele karşı sanatçının kendisinde oluşabilecek bir duygu olarak duyumsamanın etkilerini azaltıcıdır. Bu yüzden Bacon, bir içe dalış gibi modeliyle münasebete girmez. Sadece içgüdüleri ve duyumsama ilişkileri içinde sürekli devam eden bir süreci benimser (Deleuze, 2009b: 45).

Papa yorumunda onun sandalyeye sabitlenmiş hali dışında Bacon'un figürlerinde bir tür hareket dikkat çeker. Pek çok resminde Bacon, hareket halini gösterir. Ancak bu nereye doğrudur, nerede başlamış ve nerede bitecektir, belli değildir. Sınırlı bir alanın, bunun doğrudan gösterildiği gibi, dolaylı görünümlerinde kendisini hissettirmesi söz konusudur. Hareketin görünmesi, Bacon'un karşı olduğu temsil etmenin ve anlatısallığın içine düşmesi değildir. Çünkü hareket burada insani, sosyal iletişimin devamını gösteren anlamlı diziler değil, bedeni etkileyen ve nedensiz görülen "görünmez kuvvetlerin" onda uyandırdığı etkilerdir (Deleuze, 2009b: 46). Bacon'un figüral olana karşı iyimser tutumu figüratifin kendisine hissettirdikleriyle eşitlenir. Model sadece görülen değil, duyulan ve dokunulandır. Bacon'da da tüm duygulanımlar yüzeyde görsel varlığını bulur ve tüm duyumlar birleşir (Deleuze, 2009b: 47). Figürün görünmez kuvvetiyle bedenin hareketi, dar bir alandaki yürüyüşü, yüzün alanındaki gerilimler bunların hepsinin duyumları Bacon'un resminde izleyicinin karşısına çıkar. Figürü figürasyona düşürmeden, ona karşıt olan figüralin kendisine dönüştürme esastır. Deleuze, Bacon için Artaud'dan ödünç aldığı ve Guattari'yle olan düşünce üretimlerinin anahtar kelimelerinden birini, 'organsız beden' ifadesinin kullanır:

Figür, tam olarak organsız bedendir (organizmayı bedenin yararına, yüzü başın yararına bozmak); organsız beden ten ve sinirdir; üzerinde düzeyler belirleyen bir dalga katedilir; duyumsama dalgayla, beden üzerinde etkileyen Kuvvetlerin buluşması gibidir, "duygulanımsal atletizm”, soluk-çığlık; bedene böyle iletildiğinde duyumsama temsili olmayı bırakır, gerçek olur, zulüm ise giderek dehşet veren bir şeyin temsili olmaktan çıkarak sadece kuvvetlerin beden üzerindeki eylemi ya da duyumsama (sansasyonelin tersi) olur. Organ parçaları resmeden bu sefalet resminin aksine Bacon, organsız bedenler, bedenin yoğunlaştırılmış olgusunu resmetmeyi sürdürür (Deleuze, 2009b: 49).

Organsız beden, Bacon'un figürlerini karşılarken, kendi organik bütünlüğü olmadığını ifade eder. Yüzeyde görülen nedeni belirsiz ve bedenin kendi düzenini bozan kuvvetlerin oluşturduğu etki bedenin başka bir hale gelişi olmaktadır. Zamanın kendisini gösterdiği yer figürlerin bu halidir. Çünkü organsız beden "organların zamansal ve geçici mevcudiyetiyle tanımlanır” (Deleuze, 2009b: 51).

Bacon kendi zamanının dünyasını sunmasıyla değerlendirilmez. Deleuze'ün amacı, tıpkı diğer sanatçılarda olduğu gibi, sanatçının kendi döneminin ruhuna ne kadar yakın olduğu ya da onun nasıl resmettiği değildir. Elbette sanatçı kendi dönemine ait toplumun düzenini altındaki iktidar işleyişini eserlerinde hissettirir (mesela Kafka). Deleuze, sanatın bu politik yönüne değer vermekteydi. Ancak sanatçı, Deleuze için kendi zamanının sözcüsü değildir. Bacon'da olduğu gibi insan varlığına dair onu dönüştüren güçleri fark eden, figürü bu şekilde resmeden, klişelerin birikimini silendir.

Deleuze'ün Bacon ile ilgisi bir eleştirmen, sanat tarihçisi ya da felsefenin üzerine düşünebileceği nesnesini bulmasından kaynaklı bir sevinç hali olarak görülemez. Ortak bir dil şeklinde Deleuze'ün bir dizi sanatçıyla buluştuğu gibi bir izlenim mümkün görünse de, asıl önemli olan noktanın sanatın yaratım ürünlerinin bir düşünme olmasına dair iyi bir örnek sergilemesidir. Bu nedenle okunan Deleuze olduğu kadar bir izleyicinin Bacon karşısında kat ettiği yolu ifadelendirme mecburiyetini kendisinde hissetmesidir. Her ne kadar Deleuze, sanatın hiçbir söze gerek duymadığını duygulamın etkileriyle izleyicinin kendisinde buluşacağını düşünmüş olsa bile 0'nun Bacon üzerine yazdıklarının fikir verici tarafı sanatın bireylerin kullandığı dile, dolayısıyla birer klişeye dönükleşmiş anlamlar kümelenmelerine ve katmanlarına hücum edip onu zorlayabileceğidir. Bu ise günümüz sanatı için onun küresel bir kültürde dolanımda olması karşısında yakılan ağıt veya yergilerin yerine gösterilmesi gereken bir sabır işi olarak ilham vericidir. 


\section{Kaynakça}

Ballantyne, Andrew (2012). Mimarlar İçin Deleuze ve Guattari. çev: Rahmi Öğdül, İstanbul: Yem Yayın.

Bogue, Ronald (2002). Deleuze ve Guattari (Deleuze ve Guattari Üzerine Bir İnceleme).çev: İsmail Öğretir ve Ali Utku, İstanbul: Birey Yayıncılık.

Colebrook, Claire (2004). Gilles Deleuze. çev: Cem Soydemir, Ankara: Bağımsız Kitaplar.

Deleuze, Gilles ve Felix Guattari (2001). Felsefe Nedir?. çev: Turhan Ilgaz, İstanbul: Yapı Kredi Yayınları.

(2012). Anti- Ödipus. çev: Fahrettin Ege, Hakan Erdoğan ve Mustafa Yiğitalp, Ankara: Bilim ve Sosyalizm Yayınları.

Deleuze, Gilles (2009a). İki Delilik Rejimi Metinler ve Söyleşiler 1975-1995. çev: Mahir Ender Keskin, İstanbul: Bağlam Yayınları.

(2009b). Francis Bacon Duyumsamanın Mantığı. çev: Can Batukan ve Ece Erbay, İstanbul: Norgunk Yayıncılık.

(2013). Kritik ve Klinik. çev: İnci Uysal, İstanbul: Norgunk Yayınları.

Goodchild, Philip (2005). Deleuze ve Guattari Arzu Politikasına Giriş. çev: Rahmi G. Öğdül, İstanbul: Ayrıntı Yayınları.

Kılıç, Sinan (2013). Deleuze-Guattari Şizoanaliz Yaratıcı Bir Fark ve Arzu Ontolojisi. Bursa: Sentez Yayıncilık.

Sauvagnargues, Anne (2010). Deleuze ve Sanat. çev: Nurten Sarıca, İstanbul: De Ki Basım ve Yayım.

Su, Süreyya (2014). Çağdaş Sanatın Felsefi Söylemi. İstanbul: Profil Yayıncılık.

Sütcü, Özcan Yılmaz (2005). Gilles Deleuze'de İmge Hareket Olarak Sinemanın Felsefesi. İstanbul: Es Yayınları. 